\title{
ENTREPRENEURSHIP AND COMPETITIVENESS IN THE TERMS OF ENDOGENIZATION OF REGIONAL ECONOMY PROCESSES ON THE EXAMPLE OF EASTERN POLAND POVIATS IN 2007-2018
}

\author{
Paweł DZIEKAŃSKI \\ Jan Kochanowski University of Kielce, Kielce, Poland
}

\begin{abstract}
Enterprises become organizations that affect the competitiveness of poviats. The development of entrepreneurship and the competitiveness of regions are influenced by natural, social, financial, economic, and infrastructural factors. The aim of the article is to assess the diversity of the level of entrepreneurship in Eastern Poland poviats using a synthetic measure. The data from the Central Statistical Office for 2007-2018 were used as empirical material. In 2018, the entrepreneurship measure ranged from 0.22 to 0.51 , while in 2007 from 0.11 to 0.33 . The measure of competitiveness in 2018 took values from 0.28 to 0.51 , while in 2007 from 0.24 to 0.40 . The appropriate entrepreneurship potential and competitiveness of poviats affect the standard of living, the social situation, and the public safety, while they determine their future possibilities and development directions. Demographics, the sold production of industry, the gross value of fixed assets, the investment outlays and the natural persons conducting business activity have an impact on the analysed processes.
\end{abstract}

Key Words: entrepreneurship, competitiveness, synthetic measure, poviat, Eastern Poland.

\section{Introduction}

Entrepreneurship development delays in Eastern voivodships are significant. Therefore, it is necessary to identify the factors and to identify the trends of changes in the entrepreneurship and competitiveness of poviats. The level of diversity is determined, among others, by the natural conditions, the transport accessibility, the location of large settlement centers and enterprises, the access to capital, the equipment in infrastructure, the current level of economic activity, the access to knowledge and capital, the policy of local government units conducive to the growth of entrepreneurship and, thus, by competitiveness (Miłek and Kantarek 2017). Skawińska (2012) writes that entrepreneurship plays an important role in the efficient allocation of existing resources. It involves people working in the search of innovation and detecting new relationships in the existing economic and social system. The development of entrepreneurship is influenced by natural, social, financial, economic, and infrastructural (technical) factors. These factors used in market and social relations are interdependent and they occur at the same time. They should therefore be considered together. There is a correlation between the basic activities of territorial units and the level and living conditions of the residents, or the activities of enterprises. The essence of these activities is to ensure cohesion in its three dimensions: economic, social, and territorial cohesion.

Regional competitiveness attracts the attention of various circles (including entrepreneurs, politicians, scientists) due to the growing importance of regions as key elements of economic growth (Annoni and Kozovska 2010). Regional differences and imbalances are a serious obstacle to sustainable development. The assessment of the competitiveness of regions is important for an effective and efficient regional policy, and for both private and state, local and foreign investors (Ivanov 2017). Increasing the competitiveness of regions 
should be treated as an instrument to achieve the ultimate goal - social and economic development.

The aim of the article is to assess the diversity of the level of entrepreneurship in Eastern Poland poviats using a synthetic measure. The hypothesis according to which entrepreneurship is the key factor determining the development of poviats was verified. The following questions were assessed: how to measure the entrepreneurial potential of the region? Does the level of entrepreneurship in counties depend on the level of endogenous socio-economic variables in counties? What is the spatial distribution of the level of development?

\section{Literature review}

The region is a system that is set up to implement specific economic and social goals, functions, and decision-making competences. To maintain their competitive position, they must constantly seek new sources of development (OECD 2013). The competitiveness of the regional economy and its ability to develop sustainably depend not only on the location of traditional factors: land, capital and labour, but also on the knowledge and skills of its practical use. Contemporary endogenous factors play a significant role in the development of regions, including the level of qualifications of regional and local communities (OECD 1992).

The factors that may affect the development of the region or its competitiveness are very diverse, but the number of those that significantly affect this development (aspect of the multidimensionality of the process) is not only limited, but it also varies depending on the stage of development of the region. This means that one ideal development pattern is missing that leads to strengthening the competitive position of a given region (Gurria 2011). Models often emphasize that all these factors make up a hierarchical system where the significance of individual factors determining the process depends on the current level of competitiveness or development (the pyramid of competitiveness, the competitiveness tree, the hat of competitiveness) (Martin 2003).

Regional competitiveness is the ability of a given economy to optimize local assets in order to compete on the domestic and international market, as well as the ability to adapt to changes occurring in these markets (Hildebrandt and Silgoner 2007) and to achieve success in the economic competition on a global and local scale (Hatzichronoglou 1996), and by integrating these relationships in the socio-economic model (Garelli 2003). Competitiveness is a multidimensional feature of the socio-economic quality of the region's space. It determines the efficiency of using regional resources and it is reflected in the improvement of the quality of life in the region. Competitiveness is characterized by the significant diversification and asymmetry of natural, historical, cultural, social, and economic determinants. The existing factor differences make uniform rules inadequate to solve the problems of a given region, thus weakening the resources and further strengthening interregional asymmetries (Polyakova et al. 2019).

Meyer-Stamer (2016) defines the competitiveness of the territory as the ability of the regional level to generate growing income and to increase the livelihood of its inhabitants. Regional competitiveness is the region's ability to offer companies and the residents an attractive and sustainable environment for living and working. The definition of competitiveness considers not only economic but also social and environmental factors (Dijkstra et al. 2011). Dijkstra et al. (2011) built a Regional Competitiveness Index based on NUTS 2 regions, which consists of variables divided into three groups: basic (e.g. institutions, macroeconomic stability, infrastructure, health, basic education), efficiency (higher education and lifelong learning, labour market efficiency, market size), and innovation (technological readiness, business sophistication, innovation). The EU Regional Competitiveness Index $(\mathrm{RCl})$ is the first composite indicator that provides a synthetic picture 
Entrepreneurship and Competitiveness in the Terms of Endogenization of Regional Economy Processes on the Example of Eastern Poland Poviats in 2007-2018

of territorial competitiveness for $\mathrm{EU}$ regions. The authors of the $\mathrm{RCl}$ index proposed to include entrepreneurship in it. They assumed that competitiveness means the ability to provide an attractive and sustainable environment for the companies and the residents of the region where they work and live. $\mathrm{RCI}$ provides a comparable and multi-faceted picture of the level of competitiveness of all EU regions. $\mathrm{RCl}$ should be treated as an instrument supporting the design of better policies and monitoring their effectiveness (Annoni and Dijkstra 2019).

In the case of measures describing the level of competitiveness in the dimension of regional economies, researchers refer to its direct conditions. An example of different approaches in this respect may include studies prepared by Martin (2003) and Gardiner et al. (2006). Some competitiveness factors remain outside the influence of local authorities (spatial location of the commune, natural resources). Others may be more or less shaped by the local authorities (development areas, access to housing, infrastructure, social capital, workforce and entrepreneurs).

An enterprise, as an element of economic space, is one of the factors of economic development. It influences the development of regions through the efficient use of the available resources, innovative activities, or a more complete and comprehensive use of regional resources (Glinka and Gudkova 2011). The proponents of endogenous development recognize that entrepreneurship allows for sustainable, independent, and longterm development (Lipa and Karpińska 2019). In addition, endogenous development is an opportunity for peripheries to avoid growth dependent on growth centers, based, for example, on investment inflows and knowledge transfer (Endovitskaya et al. 2019). The level of entrepreneurial activity varies regionally. The owned structural features of regions and situational factors occurring in their area cause that regions differ in the scale of entrepreneurial activity. The most important benefits for the economy related to the development of entrepreneurship include a more complete satisfaction of the needs of the local community, the creation of new jobs, the liberation and strengthening of economy's innovativeness, contributing to the uniform development of regions. The existing differences between regions incline to consider the possibility of reducing them in the context of doing business (Valliere and Peterson 2009).

Entrepreneurship efficiency and an economy based on innovation enable the reduction of unemployment, the creation of jobs, they increase the propensity to undertake innovative activities, and they accelerate structural changes in the economy, and the introduction of products and services to the market that contribute to the improvement of the quality of life (Porter et al. 2002). The factors generating a kind of field of forces generating or blocking the entrepreneurship of the region include the demographic characteristics of the region, the situation on the regional labour market, the vitality of the economic structure of the region, the quality of human capital, the prestige of entrepreneurs in the region, the housing resources and their standard, and the infrastructure equipment.

\section{Methodology}

\section{Study area}

Eastern Poland (research area) covers the following voivodships: Lubelskie, Podlaskie, Podkarpackie, Świętokrzyskie and Warmińsko-Mazurskie (Fig. 1). A characteristic feature of Eastern Poland and its socio-economic space is the presence of disproportions in the development of regions. There is unequal access to basic production factors, such as capital, labour, and natural resources. Another problem for the region is the low level of economic, social, and territorial cohesion, which also results from historical conditions. The region is also characterized by a low effectiveness of the structure of the economy and the labor market, the outflow of inhabitants to other regions, and a low level of innovation 
(Ministry of Infrastructure and Development 2014). This region is characterized by a territorial and developmental peripheral character. Thanks to this, it is an interesting example for the analysis of development processes (Strojny and Kościółek 2015).
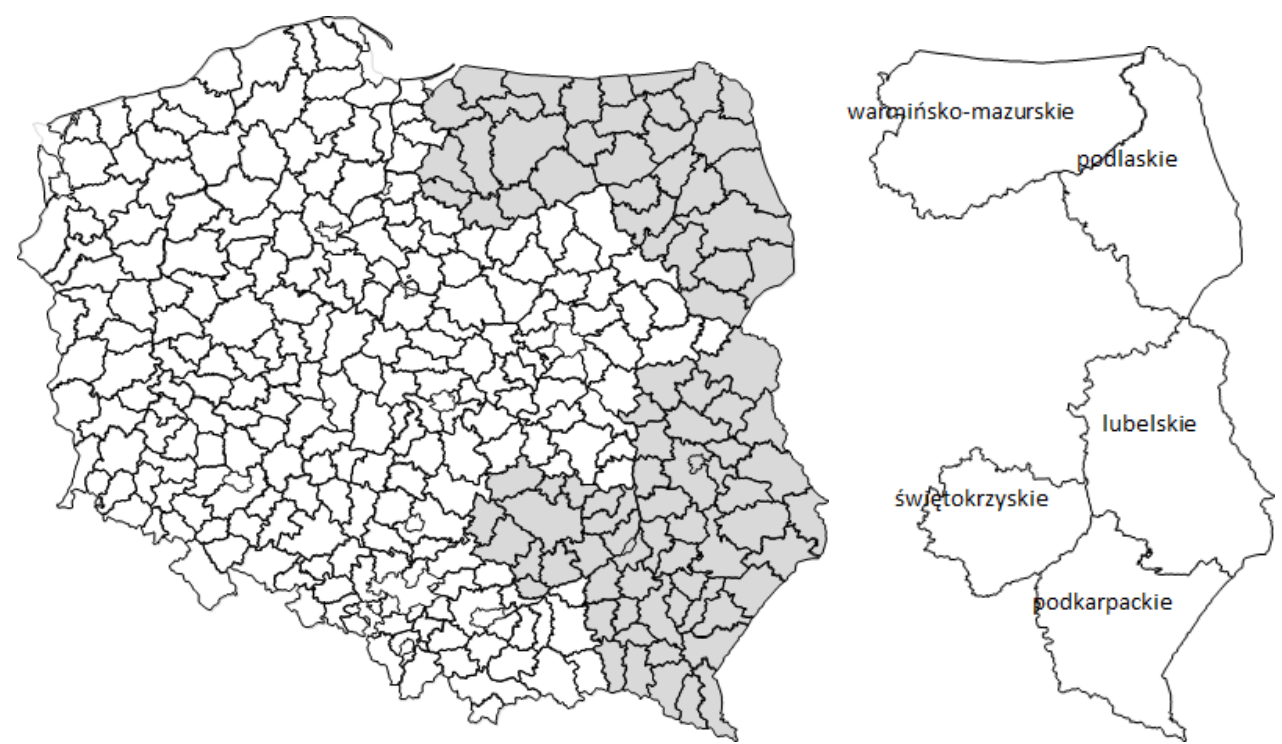

Fig. 1 - Poviats in Poland and voivodships of eastern Poland (as of August 25, 2020) Source: own study

Since January 1, 1999, a three-tier structure of local self-government has been in force in the Republic of Poland, consisting of commune, poviat and voivodeship self-government. The commune is an organization of the inhabitants of the region, and it performs public tasks not reserved by the Constitution or statutes for the organs of other public authorities (Article 163 of the Polish Constitution). The poviat is responsible, inter alia, for health care and education above the lower secondary school. The system of poviat self-government is regulated by the Act of June 5, 1998, on regional development and it allocates funds for this purpose. Jendostki have legal personality and their independence is subject to judicial protection.

\section{Entrepreneurship assessment}

In order to build synthetic measures, the Technique for Order Preference by Similarity to an Ideal Solution (TOPSIS) method was used. The aggregate value of a synthetic variable makes it easier to compare objects in multidimensional spaces. The analyses were carried out in the system of 87 poviats of Eastern Poland (20 Lubelskie Voivodship, 21 Podkarpackie Voivodship, 14 Podlaskie Voivodship, 13 Świętokrzyskie Voivodship, and 19 Warmińsko-Mazurskie Voivodship). Data from the Local Data Bank of the Central Statistical Office from 2007-2018 were used as the source material.

Several stages are distinguished in the indicated process of evaluation and classification of objects (Hellwig 1968), i.e:

I. A set of simple variables describing the studied phenomenon has been determined. The selected set of simple variables should optimally characterize the phenomenon under study. Diagnostic variables should also be of great importance in the characteristics of the analysed phenomenon, the availability of information on the variables, the weak correlation between the variables and the high degree of variability, and the relative information value 
Entrepreneurship and Competitiveness in the Terms of Endogenization of Regional Economy Processes on the Example of Eastern Poland Poviats in 2007-2018

(Kukuła and Bogocz 2014). The selected set of variables is presented in the form of an observation matrix $x_{i j}$ :

$$
x_{i j}=\left[\begin{array}{cccc}
x_{11} & x_{12} & \ldots & x_{1 m} \\
x_{21} & x_{22} & \ldots & x_{2 m} \\
\ldots & \ldots & \ldots & \ldots \\
x_{n 1} & x_{n 2} & \ldots & x_{n m}
\end{array}\right]
$$

where $x_{i j}$ denotes the values of the $\mathrm{j}$-th feature for the $\mathrm{i}$-th object $(\mathrm{i}=1,2, \ldots, \mathrm{n} ; \mathrm{j}=1,2, \ldots$, $\mathrm{m})$.

The development process is created by both economic, legal, financial, and demographic factors. They form a network of interrelated elements, and they should be considered together. The synthetic measures were determined separately for the indicated areas, using the variables listed in Table 1.

The process of verification of variables is aimed at extracting from the extracted variables such that, from the point of view of the complex phenomenon under consideration, bring the largest information and differentiating values in relation to the considered objects. From the set of variables, those characterized by a low variability (according to the coefficient of variation, the limit value was adopted at the level of 0.10) (Młodak 2006), and by a high correlation of variables (according to the inverse correlation matrix method) were removed (Malina and Zeliaś 1997).

II. In the next stage of the variable analysis, the nature of each of them was assessed, i.e. it was determined whether the variable was a stimulant or a destimulant. Destimulant variables were replaced with a stimulant, counting its inverse by the formula:

$$
x_{i j}=\frac{1}{x_{i j}}
$$

III. The next stage of building a synthetic feature is the normalization of features to introduce additivity in the sets of feature values with different titles. This is achieved by transforming their values in such a way as to obtain values without titles and harmonized as to numerical ranges (Wysocki 2010). The selected variables were subjected to the procedure of zero unitarization using the following formulas:

$$
z_{i j}=\frac{\mathrm{x}_{i j}-\min _{i} \mathrm{x}_{i j}}{\max _{i} \mathrm{x}_{i j}-\min _{i} x_{i j}} \text { when } x_{i} \in S \quad(3),
$$

where: $S$ - stimulant, $i=1,2 \ldots n, j=1,2 \ldots n, x_{i j}$ - means the value of the $j$-th feature for the examined unit, max - the maximum value of the $j$-th feature, min - the minimum value of the $j$-th feature (Kukuła and Bogocz 2014). As a result of the unitarization process, the matrix of property values was obtained $z_{i j}$ :

$$
z_{i j}=\left[\begin{array}{cccc}
z_{11} & z_{12} & \ldots & z_{1 m} \\
z_{21} & z_{22} & \ldots & z_{2 m} \\
\ldots & \ldots & \ldots & \ldots \\
z_{n 1} & z_{n 2} & \ldots & z_{n m}
\end{array}\right](4),
$$

where $z_{i j}(\in[0 ; 1])$ is the unified $x_{i j}$ value. 
List of variables describing the situation of the economic development of municipalities

\begin{tabular}{|c|c|}
\hline Variables & $\mathbf{S} / \mathbf{D}^{*}$ \\
\hline \multicolumn{2}{|l|}{ Entrepreneurial potential of the region: } \\
\hline Entities entered in the register per 1000 population & S \\
\hline Natural persons conducting economic activity per 1000 population & S \\
\hline Foundations, associations, and social organizations per 1000 inhabitants & S \\
\hline Newly registered units in the REGON register per 1000 population & S \\
\hline Units removed from the REGON register per 1000 Population & $\mathrm{D}$ \\
\hline Average monthly gross salary (total) & S \\
\hline Employed persons by section groups in total poviats (person) per 1000 inhabitants & S \\
\hline Total registered unemployment rate (\%) & $\mathrm{D}$ \\
\hline Total sold production of industry and per 1000 inhabitants (entities employing $>9$ ) (PLN) & S \\
\hline Gross value of fixed assets in enterprises per 1000 inhabitants (PLN) & S \\
\hline Investment outlays in enterprises per 1000 inhabitants (PLN) & S \\
\hline \multicolumn{2}{|l|}{ Competitive potential of the region: } \\
\hline Total migration balance per 1000 population (persons) & $\mathrm{S}$ \\
\hline Population Growth per 1000 inhabitants & S \\
\hline Total registered unemployment rate (\%) & $\mathrm{D}$ \\
\hline $\begin{array}{l}\text { Post-working age population per } 100 \text { people of working age (demographic dependency } \\
\text { ratios) }\end{array}$ & $\mathrm{D}$ \\
\hline Employed persons by section groups in total poviats (persons) & S \\
\hline Entities entered in the register per 1000 population & $\mathrm{S}$ \\
\hline Foundations, associations, and social organizations per 1000 population & S \\
\hline Total sold production of industry and per 1 inhabitant (entities employing>9) (PLN) & S \\
\hline Gross value of fixed assets in enterprises per 1 inhabitant (PLN) & S \\
\hline Investment outlays in enterprises per 1 inhabitant (PLN) & S \\
\hline Population using the water supply network (person) & S \\
\hline Population for a public pharmacy (person) & S \\
\hline $\begin{array}{l}\text { Population per } 1 \text { library institution (including library points included in accordance with the } \\
\text { head office of the parent unit) (person) }\end{array}$ & S \\
\hline Total forest area [ha] & S \\
\hline Own income per capita (PLN) & S \\
\hline Investment expenditures per capita (PLN) & S \\
\hline
\end{tabular}

${ }^{*} \mathrm{~S}$ - stimulant; D - destimulant.

Source: own study

IV. Then, synthetic measures of competitiveness and entrepreneurship based on the TOPSIS method were calculated. As part of the method, the Euclidean distances of communes from the pattern $(=1)$ and anti-pattern $(=0)$ were determined (which may indicate a segment of optimal decisions), according to the following formulas: 


$$
\begin{aligned}
& d_{i}^{+}=\sqrt{\frac{1}{n} \sum_{j=1}^{m}\left(z_{i j}-z_{j}^{+}\right)^{2}}(5), \\
& d_{i}^{-}=\sqrt{\frac{1}{n} \sum_{j=1}^{m}\left(z_{i j}-z_{j}^{-}\right)^{2}}(6),
\end{aligned}
$$

where $\mathrm{n}$ - stands for the number of variables making up the synthetic measure, $\mathrm{z}_{i j}$ stands for the unified value of the $j$-th feature for the tested unit, $z_{j}^{+}, z_{j}^{-}$- stands for the pattern or anti-pattern object (Wójcik-Leń et al. 2019).

The synthetic measure according to the TOPSIS (Technique for Order Preference by Similarity to an Ideal Solution) method was determined based on the formula (Behzadian et al. 2012):

$$
q_{i}=\frac{d_{i}^{-}}{d_{i}^{-}+d_{i}^{+}}, \text {gdzie } 0 \leq q_{i} \leq 1, i=1,2, \ldots, n
$$

where: $q_{i} \in[0 ; 1] ; d_{i}^{-}$means the distance of the object from the anti-pattern (from 0 ), $d_{i}^{+}$means the distance of the object from the pattern (from 1). A higher value of the measure indicates a better situation of the individual in the studied area (Yilmaz and Konyar 2013).

V. In the last stage of the research, the studied area was divided into 4 quartile groups. The first, the second and third quartiles were used as threshold values. The size of the synthetic measure in the first group means a better unit, and in the last one is the weakest. The mutual compliance of the obtained results was also verified based on the correlation coefficient. A scatter graph with a fit line for synthetic measures and the regression analysis is also presented (Zeliaś and Malina 1997, Dziekański 2017, Dziekański 2020, Dziekański and Prus 2020).

\section{Results and Discussion}

In 2018, the TOPSIS's entrepreneurship measure ranged from 0.22 (Chełm, Lubelskie poviat; the weakest units) to 0.51 (Mielec poviat, Podkarpackie, the best unit), and in 2007 from 0.11 (Strzyżów, Podkarpackie) to 0.33 (Ostrowiec, Świętokrzyskie). The value of myri synthetic competitiveness in 2018 ranged from 0.28 (Hrubieszów, Lubelskie; Brzozowski, Podkarpackie) to 0.51 (Mielecki, Podkarpackie), and in 2007 from 0.24 (Chełm, Hrubieszów, Lublin) to 0.40 (Mielec poviat, Podkarpackie).

The range of values adopted by the entrepreneurship measure was higher in 2018 (range 0.29 ) than in 2007 (range 0.22), while in the case of the competitiveness measure it was 0.23 in 2018, and 0.16 in 2009. This indicates a similar range of unit diversity in both areas under study, and a similar response of the units to changes in the economy. The units with an industrial character or a developed tourist function were in a better position, as well as those undergoing the impact of the local development centre (e.g. cities: Rzeszów, Kielce, Lublin, Białystok). A spatial picture of the distribution of measures is presented in Fig. 2.

The competitiveness potential of poviats is built, among others, by the financial resources of units, the occupational activity of the inhabitants, the local labour market, the entrepreneurship, infrastructure, and the condition of the natural environment. The endogenous potential resulting from the combination of local conditions determines its possibilities and directions of competitiveness development (Przybytniowski 2012).

The best and the weakest poviat of Eastern Poland differed significantly in terms of competitiveness and entrepreneurship. These are the areas shaped by location rent, local 
development centers (Rzeszów, Kielce, Lublin, Białystok, Olsztyn) and the developing labour market and growth in the SME sector. Regions located peripherally (poviats of Eastern Poland in the context of the EU area) relative to the centre are characterized by, among others, the effect of leaching social potential (sucking the potential from the periphery to the centre), which is manifested in the balance of migration. This means that often a centre develops at the expense of small units. According to Rosner (2012), there is a close relationship between the processes regarding the population (population, age and occupational structure, birth rate, migration balance) and the level of socio-economic development or competitiveness.

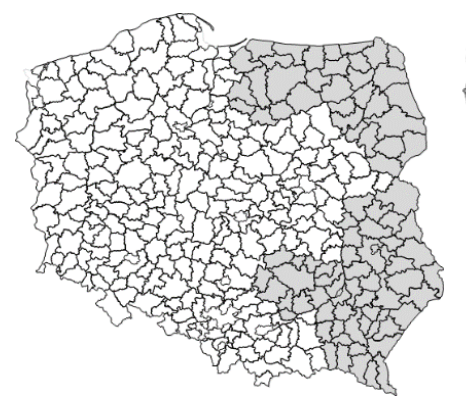

Gr I
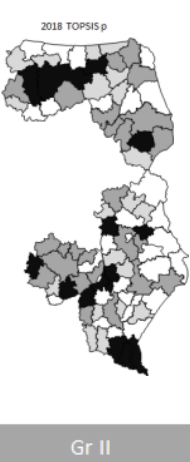

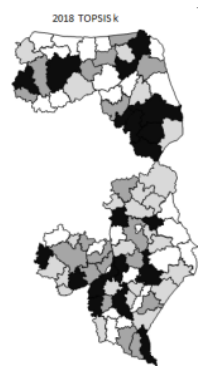

Gr III

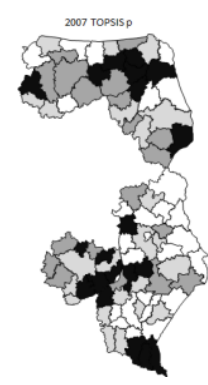

Gr IV

TOPSIS p - entrepreneurship; TOPIS $k$ - competitiveness;

Black - the best units; Brighter - the weaker units.

Fig. 2 - Spatial diversity of entrepreneurship and competitiveness of Eastern Poland poviats in 2007 and 2018

Source: own development based on the data from the Local Data Bank of the Central Statistical Office

The histogram (Fig. 3) indicates the distribution model for the measure of synthetic entrepreneurship (2018 - left-sided, 2007 - right-sided) and competitiveness (2018 - leftsided, 2007 - right-sided). The synthetic measure was $0.22-0.51$ and $0.11-0.33$, and it had a range of $0.22-0.29$ (2007-2018) in the case of the entrepreneurship measure. In the case of the competitiveness measure, respectively: $0.28-0.51 ; 0.16-0.24$ and $0.16-0.23$. The most numerous range in 2018 was $0.30-0.35$ (25/87, measure of entrepreneurship), followed by $0.34-0.36(19 / 87$, measure of competitiveness), which means that there is a dominant in this range.

For the measures of spatial diversity in the case of entrepreneurship in 2018 compared to 2007, the results show an increase in diversity according to the standard deviation (0.05$0.06)$, the quarter deviation (0.20-0.33), and the range value (0.22-0.29). Also, for the competitiveness measure - the standard deviation (0.03-0.05), the quarter deviation (0.33$0.38)$, the classic coefficient of variation $(0.11-0.12)$ and the range $(0.16-0.23)$, respectively (Table 2).

The Pearson correlation coefficient between the value of the synthetic entrepreneurship measure in 2018 compared to 2007 was 0.694 , and in the case of the competitiveness measure -0.751 . In the case of the relation measure of entrepreneurship to the measure of competitiveness in $2007-0.585$, in $2018-0.780$ (Fig. 4). The spatial diversity of the studied area was quite stable. The units reacted similarly to the changes in the economy. Two groups of outliers can be identified, i.e. the first is characterized by a developed industrial function, good situation in both studied areas, and location in the area of influence of a strong urban unit (e.g. the group consists of units with low entrepreneurship and competitiveness potential - Chełm, Hrubieszów, Brzozowski, and Kolno poviats). 
Entrepreneurship and Competitiveness in the Terms of Endogenization of Regional Economy Processes on the Example of Eastern Poland Poviats in 2007-2018
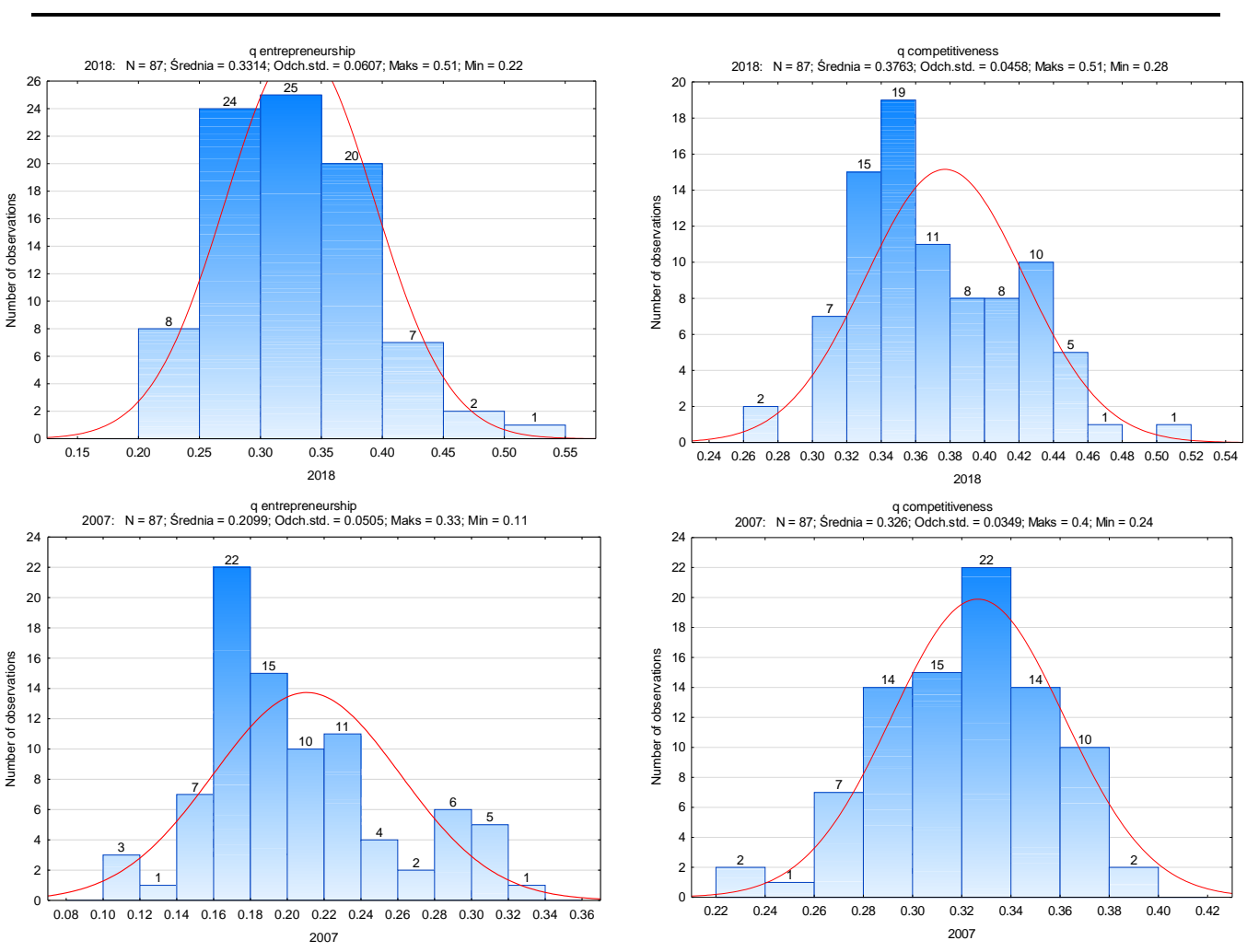

Fig. 3 - The measure of synthetic entrepreneurship and competitiveness of Eastern Poland poviats in 2007 and 2018

Source: own development based on the data from the Local Data Bank of the Central Statistical Office

Table 2

The diversity of entrepreneurship and competitiveness measures of Eastern Poland poviats in 2007 and 2018

\begin{tabular}{|l|c|c|c|c|}
\hline & \multicolumn{2}{|c|}{ q entrepreneurship } & \multicolumn{2}{c|}{ q competitiveness } \\
\hline & $\mathbf{2 0 0 7}$ & $\mathbf{2 0 1 8}$ & $\mathbf{2 0 0 7}$ & $\mathbf{2 0 1 8}$ \\
\hline Average & 0.21 & 0.33 & 0.33 & 0.38 \\
\hline Standard Deviation & 0.05 & 0.06 & 0.03 & 0.05 \\
\hline Quarter (Quartile) Deviation & 0.20 & 0.33 & 0.33 & 0.38 \\
\hline $\begin{array}{l}\text { Classic Coefficient of } \\
\text { Variation }\end{array}$ & 0.24 & 0.18 & 0.11 & 0.12 \\
\hline $\begin{array}{l}\text { Positional Coefficient of } \\
\text { Variation }\end{array}$ & 1.00 & 1.04 & 0.98 & 1.01 \\
\hline Min. & 0.11 & 0.22 & 0.24 & 0.28 \\
\hline Max. & 0.33 & 0.51 & 0.40 & 0.51 \\
\hline Range & 0.22 & 0.29 & 0.16 & 0.23 \\
\hline Quartile Range & 0.06 & 0.10 & 0.05 & 0.07 \\
\hline
\end{tabular}

Source: own study based on the data from the Local Data Bank of the Central Statistical Office 

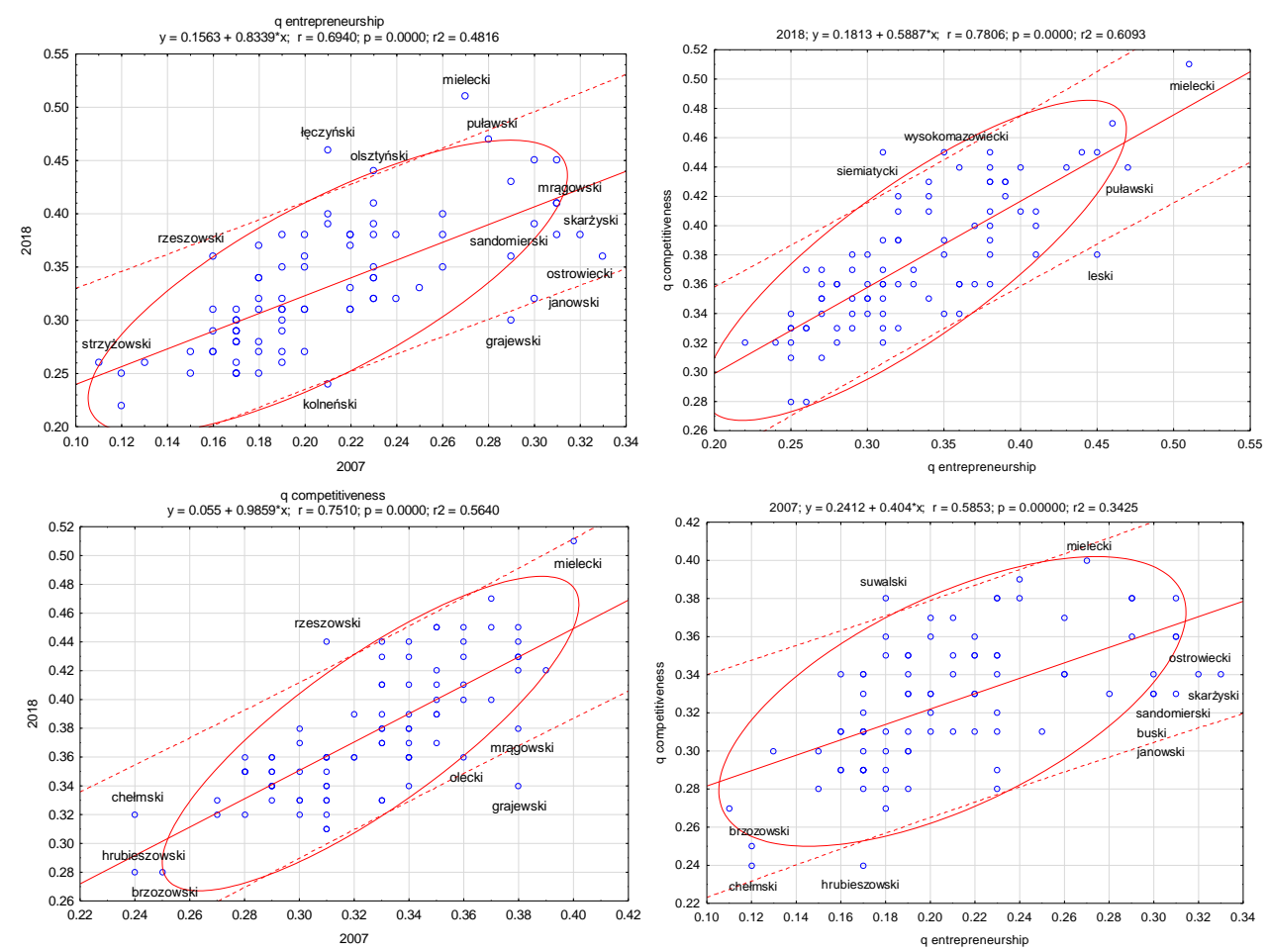

Fig. 4 - The adjustment line of synthetic measures of entrepreneurship and competitiveness of Eastern Poland Poviats in 2007 and 2018

Source: own development based on the data from the Local Data Bank of the Central Statistical Office

The correlation coefficient between the values of the measures of endogenous potential of the region indicates positive correlations with the exception of the demographic area (in the case of peripheral areas, the process of social capital is leaching). The highest correlation value of the entrepreneurship measure was with competitiveness (0.729) and with the financial situation (0.475) and infrastructure $(0.464$, Table 3$)$. The results obtained may indicate the stability of spatial diversity in the examined aspect and a similar reaction of individuals to the changes in the economy.

Competitiveness of the local government is perceived in the context of its ability to adapt to positive trends appearing in the environment (e.g., development of entrepreneurship, creation of local development). Competitiveness potential is the total of tangible and intangible resources of an organization, necessary for it to function. Myrdal, in the theory of cumulative causation referring to the analysis of the interdependence of social, economic, and institutional phenomena, has proved that every element interacting with another element affects its behaviour, and, at the same time, it is modified by the reaction of that element (Stanny and Strzelczyk 2018).

The financial situation of the poviat is closely correlated with the level of competitiveness, the standard of living of the inhabitants and the functioning of business entities. It translates into disproportions in the scope of the ability to meet the local needs or the manner and quality of public tasks' implementation. Financial resources are the basis for the operation of the unit and a condition for the implementation of its statutory tasks (related to, among others, solving social problems, taking actions related to the needs of the residents). A high correlation value with PIT and CIT revenues may indicate that poviats are dependent on the revenues from the state budget. The costs incurred by the poviats for the development of 
Entrepreneurship and Competitiveness in the Terms of Endogenization of Regional Economy Processes on the Example of Eastern Poland Poviats in 2007-2018

technical and social infrastructure lead to the development of entrepreneurship. These investments, combined with the activity of the inhabitants, should favour the creation of new and the development of existing enterprises.

Table 3

Correlation between the basic endogenous potentials of Eastern Poland poviats

\begin{tabular}{|c|c|c|c|c|c|c|}
\hline 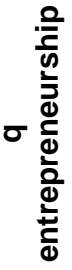 & 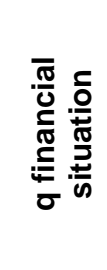 & 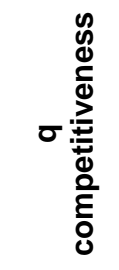 & 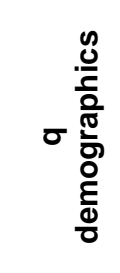 & 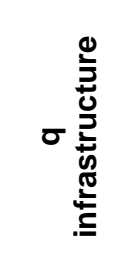 & 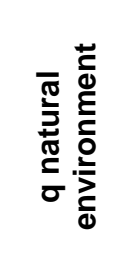 & \\
\hline \multirow[t]{6}{*}{1} & 0.4753 & 0.7298 & -0.1778 & 0.4644 & 0.364 & $\stackrel{q}{\text { entrepreneurship }}$ \\
\hline & 1 & 0.5232 & -0.0443 & 0.1673 & 0.1637 & $\begin{array}{c}\mathrm{q} \text { financial } \\
\text { situation }\end{array}$ \\
\hline & & 1 & 0.1647 & 0.3819 & 0.3512 & $\begin{array}{c}\mathrm{q} \\
\text { competitiveness } \\
\end{array}$ \\
\hline & & & 1 & -0.2039 & 0.0104 & $\begin{array}{c}q \\
\text { demographics }\end{array}$ \\
\hline & & & & 1 & 0.5277 & $\begin{array}{c}\mathrm{q} \\
\text { infrastructure }\end{array}$ \\
\hline & & & & & 1 & $\begin{array}{c}\text { q natural } \\
\text { environment }\end{array}$ \\
\hline
\end{tabular}

Linear correlation coefficients for observations from sample 1-1044; Critical value (at a 5\% bilateral critical area) $=0.0607$ for $n=1044$

Source: own study based on the data from the Local Data Bank of the Central Statistical Office

Infrastructure is one of the main conditions shaping the competitiveness (development) possibilities of regions, both on the economic, social, and ecological level. It influences the processes taking place in the regions by creating conditions for improving the attractiveness of a given area for the current and potential residents, enterprises, and investors. The poviats (including communes within the poviat), by investing in road infrastructure and utilities, better meet the needs of the local community, while making it easier for entrepreneurs to run their business. The competitiveness of regions is also increasing, which attracts the attention of potential investors.

The synthetic measure of entrepreneurship in relation to the socio-economic elements presents positive and negative correlation values. The most correlated measure was the share in income from PIT and CIT, the sold production of industry, the gross value of fixed assets, the investment outlays, the employed in industry, as well as trade and repair, entities and natural persons conducting an economic activity (Table 4).

The economy cannot develop without an adequate human potential. Its migrations cause changes in the area of population structure or spatial distribution. The change in the number of economic entities is a positive impulse to support entrepreneurship. Local authorities should also improve the condition of infrastructure. Its quality and condition affect the attractiveness of the area, the increase in the number of companies, jobs, and the quality of life of the inhabitants. 
Correlation between the entrepreneurship measure and the simple features shaping it in Eastern Poland poviats

\begin{tabular}{|l|c|}
\hline & q entrepreneurship \\
\hline Own income & 0.3065 \\
\hline Investment expenditure & -0.0351 \\
\hline Share in PIT and CIT revenues & 0.4316 \\
\hline Industrial output sold & 0.5005 \\
\hline Gross value of fixed assets & 0.6265 \\
\hline Investment outlays & 0.5076 \\
\hline Number of employed persons & 0.1072 \\
\hline Employed in agriculture & -0.2608 \\
\hline Employed in industry & 0.4909 \\
\hline Working in trade and repair & 0.5286 \\
\hline Registered unemployed persons & -0.3471 \\
\hline Economic operators & 0.7692 \\
\hline Self-employed persons & 0.7438 \\
\hline Net migration rate & 0.0634 \\
\hline Housing stock & 0.2484 \\
\hline Forest areas & -0.114 \\
\hline
\end{tabular}

Linear correlation coefficients for observations from sample 1-1044;

Critical value (at a 5\% bilateral critical area) $=0.0607$ for $n=1044$.

Source: own study based on the data from the Local Data Bank of the Central Statistical Office

The regression analysis of the measure of synthetic entrepreneurship and the endogenous potentials of Eastern Poland poviats allows explaining the $R=0.645$ variable variations. The model indicates the important role of the basic endogenous potentials of poviats (financial situation, competitiveness, demography, infrastructure, natural environment) in the development of entrepreneurship in the economy. The statistics values $F(5,1038) 378.5477$ and the corresponding probability level $p$ mean that all parameters are statistically significant. The further increasing of the multidimensionality of the model would cause a small increase in R2 0.644 (Table 5) ${ }^{1}$.

The regression analysis of the measure of synthetic entrepreneurship and the simple variables pouring on it (according to the correlation values) allows to explain the $R=0.786$ variable variations. The model indicates the important role of participation in PIT and CIT revenues, of investment expenditure, of persons employed in agriculture and industry, of the unemployed, of the entities and natural persons conducting an economic activity, as well as of migration balances in the process of entrepreneurship development in the local economy. The statistics values $F(8,1035) 476.4623$ and the corresponding probability level $p$ mean that all parameters are statistically significant. The further increasing of the multidimensionality of the model would cause a small increase in the R2 (0.784, Table 6).

${ }^{1}$ The adjusted determination ratio did not reach $60 \%$. The optimal value is considered exceeding the $95 \%$ determination threshold. 
Entrepreneurship and Competitiveness in the Terms of Endogenization of Regional Economy Processes on the Example of Eastern Poland Poviats in 2007-2018

Table 5

KMNK regression model of the synthetic measure entrepreneurship in relation to the variable synthetic endogenous potentials of Eastern Poland poviats

\begin{tabular}{|c|c|c|c|c|c|c|c|}
\hline & & Coefficient & Standar & d error & t-Student's & & value \\
\hline Constant & & -0.198820 & 0.0177 & 7308 & -11.21 & & .0001 \\
\hline q financial situation & & 0.211795 & 0.052 & 7102 & 4.018 & & .0001 \\
\hline q competitiveness & & 1.07450 & 0.039 & 9117 & 26.92 & & .0001 \\
\hline q demographics & & -0.148000 & 0.011 & 3345 & -13.06 & & .0001 \\
\hline q infrastructure & & 0.147166 & 0.031 & 2805 & 4.705 & & .0001 \\
\hline q natural environmen & & 0.0910867 & 0.033 & 3182 & 2.734 & & 0064 \\
\hline $\begin{array}{l}\text { Arithmetic mean of the } \\
\text { dependent variable }\end{array}$ & 0.256418 & 8 Logarithn & dibility & 1924.948 & Corrected $R$-s & & 0.644117 \\
\hline $\begin{array}{l}\text { Residual sum of } \\
\text { squares }\end{array}$ & 1.530045 & $5 \begin{array}{l}\text { Bayesian in } \\
\text { criterion Scl }\end{array}$ & $\begin{array}{l}\text { rmation } \\
\text { larza }\end{array}$ & -3808.192 & $P$-value for the & test & $5,2 e-231$ \\
\hline $\begin{array}{l}\text { Determining the } \\
\text { coefficient } \\
R \text {-square } \\
\end{array}$ & 0.645823 & $3 \begin{array}{l}\text { Standard } d \epsilon \\
\text { dependent }\end{array}$ & $\begin{array}{l}\text { iation of } \\
\text { riable }\end{array}$ & 0.064358 & $\begin{array}{l}\text { Information cr } \\
\text { Akaike'a }\end{array}$ & & -3837.897 \\
\hline$F(5,1038)$ & 378.5477 & $7 \begin{array}{l}\text { Residual s } \\
\text { error }\end{array}$ & ard & 0.038393 & $\begin{array}{l}\text { Crit. Hannan } \\
\text { Quinna }\end{array}$ & & -3826.630 \\
\hline
\end{tabular}

The observations used 1-1044; Dependent variable: q entrepreneurship.

Source: own study based on the data from the Local Data Bank of the Central Statistical Office

Table 6

KMNK regression model - a synthetic measure of entrepreneurship in relation to the socio-economic elements of Eastern Poland poviats

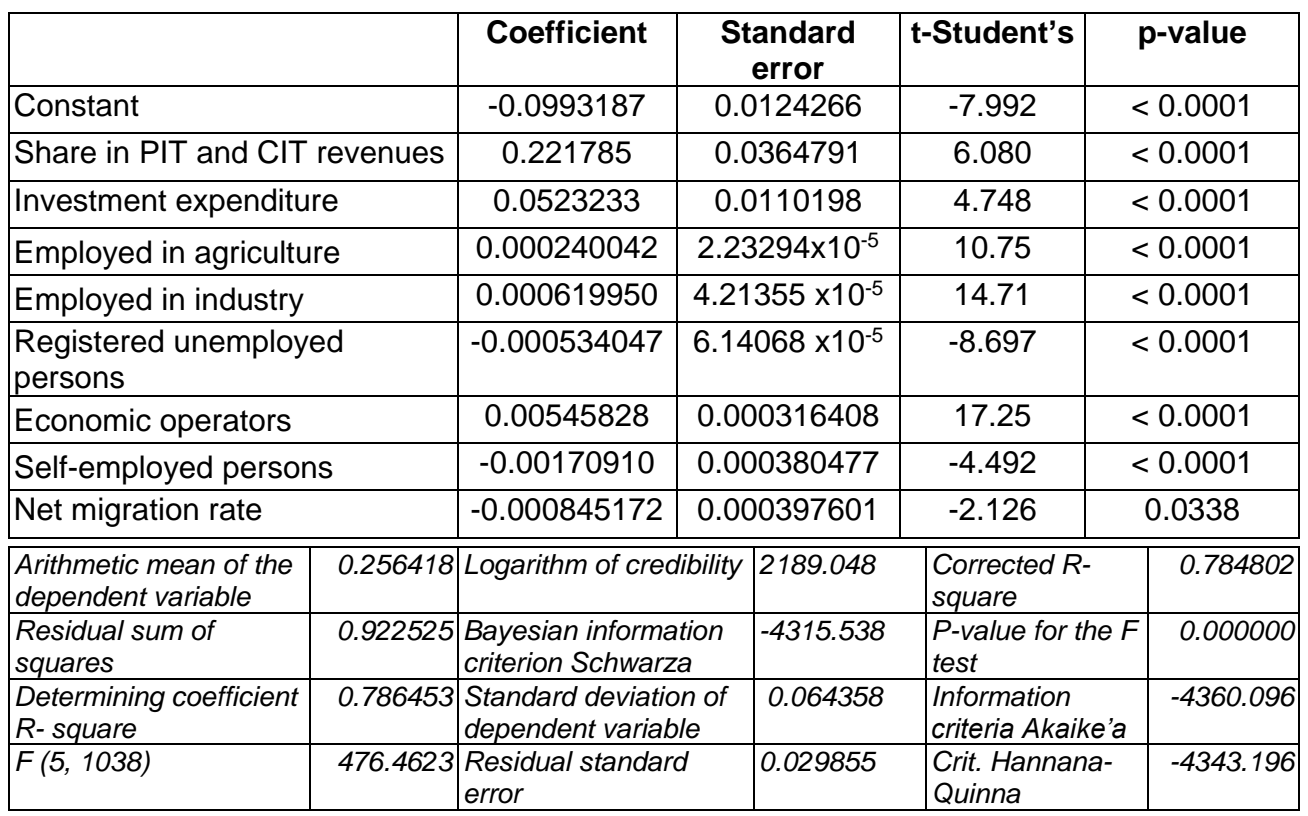

The observations used 1-1044; Dependent variable: q entrepreneurship.

Source: own study based on the data from the Local Data Bank of the Central Statistical Office 


\section{Conclusions}

Poviats have individual natural, social, and economic features that can constitute resources determining the possibilities of their functioning. Competitiveness contributes to the growth of economic potential (development) and to the increase in the quality of life of the residents. A high level of competitiveness creates good conditions for ensuring a higher standard of living for the residents, and the further development of entrepreneurship.

In 2018, the TOPSIS entrepreneurship measure ranged from 0.22 to 0.51 , while in 2007 from 0.11 to 0.33 . The measure of competitiveness in 2018 took values from 0.28 to 0.51 , while in 2007 from 0.24 to 0.40 . This indicates a similar range of unit diversity in both areas under study, and a similar response of the units to the changes in the economy.

The poviats with the highest level of competitiveness are located in the vicinity of urban centres, industrial centres, and in the vicinity of transport routes - which positively stimulates the processes of the local economy, while the weakest units are often characterized by a traditional agricultural function.

The appropriate entrepreneurship potential and the competitiveness of poviats affect the standard of living, the social situation, public safety, and they determine the regional possibilities and development directions. Human resources and endo-ethnic capitals in the region are shrinking due to leaching effects. They seem to be strongly dependent on the transfer revenues from the state budget.

The correlation coefficient between the values of the measures of the endogenous potential of the region indicates positive correlations with entrepreneurship except for the area of demography (in the case of peripheral areas, the process of social capital is leaching). The highest correlation value of the measure of entrepreneurship was with competitiveness, as well as with the financial situation and the infrastructure. The results obtained may indicate the stability of spatial diversity in the examined aspect and a similar reaction of the individuals to the changes in the economy. The measure of entrepreneurship was to the greatest extent correlated with the share in income from the PIT and CIT, the industrial production sold, the gross value of fixed assets, the investment outlays, the number of employed in industry, as well as trade and repair, the entities and natural persons conducting a business activity.

The results of the study give the local governments the opportunity to compare their own situation with the situation of neighbouring municipalities. The conclusions drawn on this basis may allow the local authorities to set out potential directions for optimizing the structure of the local finances or the competitiveness process. When assessing the changes over time, it should be remembered that small changes in the results should not be considered as information (they may result from the slight differences between regions).

\section{References}

ANNONI P., DIJKSTRA L. (2019), The EU Regional Competitiveness Index 2019, Publications Office of the European Union, Luxembourg.

ANNONI P., KOZOVSKA K. (2010), EU regional competitiveness index 2010 , Publications Office of the European Union, Luxembourg.

BEHZADIAN M., OTAGHSARA S. K., YAZDANI M., IGNATIUS J. (2012), A state-of the-art survey of TOPSIS applications, Expert Systems with Applications 39 (17), 1305113069.

DIJKSTRA L., ANNONI P., KOZOVSKA K. (2011), A New Regional Competitiveness Index: Theory, Methods and Findings, European Commission. Regional Policy, Retrieved from: www.ec.europa.eu. 
Entrepreneurship and Competitiveness in the Terms of Endogenization of Regional Economy Processes on the Example of Eastern Poland Poviats in 2007-2018

DZIEKAŃSKI P. (2017), Diversification Synthetic Indicator for Evaluating the Financial Capacity of Local Government. The Case of Polish Voivodeships, Acta Universitatis Agriculturae et Silviculturae Mendelianae Brunensis 65 (2), 611-619.

DZIEKAŃSKI P. (2020), Differentiation of the financial standing of the municipalities of Świętokrzyskie voivodeship in the aspect of their financial independence, Optimum. Economic Studies 3 (101), 41-55.

DZIEKAŃSKI P., PRUS P. (2020), Financial Diversity and the Development Process: Case study of Rural Communes of Eastern Poland in 2009-2018, Sustainability 12 (16), 6446.

ENDOVITSKAYA E. V., RISIN I. E., TRESHCHEVSKY Y. I. (2019), Strategic Goals of Socio-Economic Development of Regions in the Conditions of Economic and Financial Limitations, in: Popkova E. (ed.), The Future of the Global Financial System: Downfall or Harmony. ISC 2018. Lecture Notes in Networks and Systems 57, Springer, Cham, pp. 229235.

GARDINER B., MARTIN R., TYLER P. (2006), Competitiveness, Productivity and Economic Growth across the European Regions, in: Martin R., Kitson M., Tyler P. (eds.), Regional Competitiveness, Routledge, London, pp. 55-78.

GARELLI S. (2003), Competitiveness of nations: the fundamentals, IMD World Competitiveness Yearbook, Lausanne.

GLINKA B., GUDKOVA S. (2011), Przedsiębiorczość (Entrepreneurship), Wolters Kluwer, Warsaw.

GURRIA A. (2011), Stability and Growth: What Role for EU Cohesion Policy? OECD, Retrieved from: www.oecd.org.

HATZICHRONOGLOU T. (1996), Globalisation and competitiveness: relevant indicators, OECD Publishing, Paris.

HELLWIG Z. (1968), Zastosowanie metody taksonomicznej do typologicznego podziału krajów ze względu na poziom rozwoju oraz zasoby i strukture wykwalifikowanych kadr (Application of the taxonomic method to the typological division of countries according to the level of development as well as resources and structure of qualified personnel), Przeglad Statystyczny 4, 307-326.

HILDEBRANDT A., SILGONER M. A. (2007), The Competitiveness Challenge: EU Member States in International Trade, Monetary Policy \& the Economy Q4 (7), 67-88.

IVANOV I. (2017), Dynamics of competitiveness of the regions in Bulgaria, Trakia Journal of Sciences 15 (S1), 42-50.

KUKUŁA K., BOGOCZ D. (2014), Zero unitarization method and its application in ranking research in agriculture, Economic and Regional Studies 7 (3), 5-13.

LIPA A., KARPINSKA U. (2019), Entrepreneurship as endogenous development potential of communes in the Świętokrzyskie province, Regional Journal 19, 100-114.

MALINA A., ZELIAŚ A. (1997), Taksonomiczna analiza przestrzennego zróżnicowania jakości życia ludności w Polsce w 1994 r. (Taxonomic analysis of spatial differentiation in the quality of life of the population in Poland in 1994), Przegląd Statystyczny 44 (1), 11-27.

MARTIN R. L. (2003), A Study of the Factors of Regional Competitiveness Cambridge Econometrics, ECORYS-NEI, Retrieved from: www.ec.europa.eu.

MEYER-STAMER J. (2016), Systemic Competitiveness and Local Economic Development, in: Bodhanya S. (ed.), Large Scale Systemic Change: Theories, Modelling and Practices, Nova, New York.

MIŁEK D., KANTAREK I. (2017), Przedsiębiorczość w rozwoju polskich regionów (Entrepreneurship in the development of Polish regions), Nierówności Społeczne a Wzrost Gospodarczy 50 (2), 315-328.

MINISTRY OF INFRASTRUCTURE AND DEVELOPMENT (2014), Program Operacyjny: Polska Wschodnia 2014-2020 (Operational Program: Eastern Poland 20142020), Ministerstwo Infrastruktury i Rozwoju, Warsaw.

MŁODAK A. (2006), Analiza taksonomiczna w statystyce regionalnej (Taxonomic analysis in regional statistics), Difin, Warsaw. 
OECD (1992), Technology and the economy: the key relationships, OECD Publications, Paris.

OECD (2013), Innovation-driven growth in regions: the role of smart specialisation, OECD Publications, Paris.

POLYAKOVA A., KOLMAKOV V., YAMOVA O. (2019), Regional Competitiveness Response to Innovation Changes: Issues of Evaluation, Journal of Urban and Regional Analysis 11 (2), 159-172.

PORTER M. E., SACHS J. D., MCARTHUR J. W. (2002), Executive Summary: Competitiveness and Stages of Economic Development, in: Schwab K., Porter M. E., Sachs J. D. (eds.), The Global Competitiveness Report 2001-2002, Oxford University Press, Oxford, pp. 16-25.

PRZYBYTNIOWSKI J. W. (2012), The Importance of Environmental insurance as an Economic and Financial Instrument, Political Sciences 15 (2), 174-184.

ROSNER A. (2012), Zmiany rozkładu przestrzennego zaludnienia obszarów wiejskich. Wiejskie obszary zmniejszające zaludnienie $i$ koncentrujące ludność wiejską (Changes in the spatial distribution of population in rural areas. Rural areas that diminish the population and concentrate the rural population), IRWiR PAN, Warsaw.

SKAWIŃSKA E. (2012), Kapitał społeczny w rozwoju region (Social capital in the development of the region), PWN, Warsaw.

STANNY M., STRZELCZYK W. (2018), Kondycja finansowa samorządów lokalnych a rozwój społeczno-gospodarczy obszarów wiejskich: Ujęcie przestrzenne (Financial condition of local self-governments and the socio-economic development of rural areas: Spatial shot), IRWiR PAN, Wyd. Naukowe Scholar Spółka z o.o., Warsaw.

STROJNY J., KOŚCIÓŁEK M. (2015), Entrepreneurship in Eastern Poland - the evaluation of development potential using comparative analysis, Entrepreneurship Education 11, 64-81.

VALLIERE D., PETERSON R. (2009), Entrepreneurship and Economic Growth: Evidence from Emerging and Developed Countries, Entrepreneurship \& Regional Development 21 (5-6), 459-480.

WÓJCIK-LEŃ J., LEŃ P., MIKA M., KRYSZK H., KOTLARZ P. (2019), Studies regarding correct selection of statistical methods for the needs of increasing the efficiency of identification of land for consolidation-A case study in Poland, Land Use Policy 87, 104064.

WYSOCKI F. (2010), Metody taksonomiczne $w$ rozpoznawaniu typów ekonomicznych rolnictwa $i$ obszarów wiejskich (Taxonomic methods in recognizing economic types of agriculture and rural areas), Uniwersytetu Przyrodniczego w Poznaniu, Poznan.

YILMAZ B. B., KONYAR A. M. (2013), Financial Performance Evaluation of Publicly held Lodging Companies Listed in Istanbul Stock Exchange with TOPSIS Method, European Journal of Scientific Research 95 (1), 143-151.

ZELIAŚ A., MALINA A. (1997), O budowie taksonomicznej miary jakości życia. Syntetyczna miara rozwoju jest narzędziem statystycznej analizy porównawczej (On the construction of a taxonomic measure of the quality of life. The synthetic measure of development is a tool for statistical comparative analysis), Taksonomia 4, 238-262.

Initial submission: 22.04.2020

Revised submission: 21.10 .2020

Final acceptance: 01.12.2020

Correspondence: Department of Economics and Finance, Jan Kochanowski University of Kielce, Uniwersytecka 15 str., 25-406 Kielce, Poland.

Email: pawel.dziekanski@ujk.edu.pl 